\title{
Minimum Authorized Capital After the Enactment of Job Creation Law: Status Quo, Controversies, and Road Ahead
}

\author{
Kania Jennifer Wiryadi* \\ University of Indonesia, Indonesia \\ Bayu Novendra \\ University of Indonesia, Indonesia
}

\begin{abstract}
In a limited liability company, capital becomes one of the primary elements. However, the regulation regarding capital in Indonesia has changed several times, as its latest concern on the enactment of the omnibus bill on Job Creation Law in 2020. This paper discussed the following problems. First, what are the status quo and the development of regulations regarding minimum capital requirements in Indonesia? Second, what are the pros and cons of minimum capital requirement regulations and their developments in other countries? Third, what is the minimum capital requirements regulation that suits the conditions in Indonesia? This paper used legal research, emphasizing literature study. In so doing, the data were analyzed with the deductive method to construct conclusions. This paper showed that each limited liability company from the 1995 Limited Company Law, the 2007 Limited Company Law to the Job Creation Law had various minimum capital requirements provisions that lasted to its abolishment under the Job Creation Law. In this context, the initial policy on the minimum capital requirement was to protect creditors. In practice, however, this policy was not effective because many other effective alternatives to protect creditors, by encouraging transparency in corporate transactions and offering easy access to corporate information. The dominance of micro and small business units in Indonesia (99\% of business units) explains the urgency of eliminating minimum capital requirements regulations. The elimination of minimum authorized capital requirements is a tremendous effort to strengthen micro and small enterprises.
\end{abstract}

KEYWORDS: Limited Liability Company, Job Creation Law, Company Law.

\section{Copyright $@ 2021$ by Author(s)}

This work is licensed under a Creative Commons Attribution-ShareAlike 4.0 International License. All writings published in this journal are personal views of the authors and do not represent the views of this journal and the author's affiliated institutions.

\section{HOW TO CITE:}

Wiryadi, Kania Jennifer \& Bayu Novendra, "Minimum Authorized Capital After the

Enactment of Job Creation Law: Status Quo, Controversies, and Road Ahead" (2021) 8:1 Lentera Hukum 1-22. DOI: <https://doi.org/10.19184/ejlh.v8i1.21946>.

Submitted: 11/01/2021 Reviewed: 13/01/2021 Revised: 20/02/2021 Accepted: 26/02/2021

\footnotetext{
* Corresponding author’s e-mail: kaniawiryadi@gmail.com
} 


\section{INTRODUCTION}

The enactment of the Job Creation Law No. 11 of 2020 became one of Indonesia's breakthroughs. This law used the omnibus law method adopted from the common law tradition. ${ }^{1}$ In common law tradition countries, this method is applied to avoid political deadlock due to the complexity of law contents; this method compromises different interests with each parliament member to accommodate the desired substance. ${ }^{2}$ Through the Job Creation Law, the government expected to attract more investments by simplifying regulations so that Indonesia's rules become more business friendly. This objective referred to Indonesia's ease of doing business ranking that was much lower than its neighboring countries such as Thailand, Malaysia, and Singapore. In the 2019 rankings, Indonesia was $73^{\text {rd }}$, while Thailand, Malaysia, and Singapore were $21^{\text {st }}, 12^{\text {th }}$, and $2^{\text {nd }}$, respectively. ${ }^{3}$ Through the Job Creation Law, 73 laws with the same and relevant sectors were amended and merged, including the limited liability company.

The Job Creation Law changed the definition of a limited liability company. There was an addition of the phrase, "individual legal entities that meet the criteria of micro and small businesses as stipulated in the laws and regulations regarding micro and small enterprises." Consequently, micro and small enterprises' limited liability companies could be established with only one shareholder. Therefore, a limited liability company is a legal entity that is a capital partnership. In the case of a micro and small business, it could only consist of one shareholder. Thus, in a limited liability company, capital became one of the primary elements. However, it turned out that the regulation regarding this capital in Indonesia has changed several times. One of the significant changes was about the minimum authorized capital, abolished in this Job Creation Law. Then, it relied upon the freedom of the founders' limited liability company.

1 Bayu Dwi Anggono \& Fahmi Ramadhan Firdaus, "Omnibus Law in Indonesia: A Comparison to the United States and Ireland" (2020) 7:3 Lentera Hukum.

2 Ibid.

3 Doing Business, "Ease of Doing Business Rankings" Doing Business (2019) online: <https://www.doingbusiness.org/en/rankings>. 
To date, the regulation regarding capital in Indonesia has changed several times, with its significant change after enacting the Job Creation Law. It confirms the rules for eliminating the minimum authorized capital requirements previously regulated by Government Regulation No. 29 of 2016 to lead to confusion. Subsequently, this paper dissected regulations and practices in various countries and analyzed previous studies discussing the minimum authorized capital requirements. Despite some advantages and disadvantages, the objective of the minimum capital requirement to protect creditors was ineffective. There were many other effective alternatives to protect creditors by encouraging transparency in corporate transactions and offering easy access to corporate information. Given the condition of business units in Indonesia dominated by micro and small units, access to limited liability companies played a significant role. Then, abolishing the minimum authority capital requirement had positive implications for Indonesia's future business.

This paper will discuss three main issues. First, what are the status quo and the history of regulations regarding minimum authorized capital requirements in Indonesia? Second, what are the pros and cons of minimum capital requirement regulations and their development in other countries? Finally, what are the minimum authorized capital requirements regulation that matches the conditions in Indonesia?

\section{METHODS}

This method was legal research, often referred to as dogmatic legal research or theoretical legal research. This research provided written emphasis on research on library law materials. In so doing, this paper used descriptive qualitative analysis, which describes existing data or cases descriptively to conclude the data-drawing conclusions using the deductive method, by concluding general questions to reach specific conclusions. The data were primary and secondary legal materials. Primary legal materials were binding legal materials such as basic norms or rules. Simultaneously, secondary legal materials were legal materials to explain primary legal materials, such as books, journal articles, academic manuscripts, dictionaries, and web pages. 


\section{THE MINIMUM AUTHORIZED CAPITAL IN INDONESIA'S LEGISLATION: AN OVERVIEW}

In Indonesia, based on Limited Liability Company Law No. 40 of 2007, the company's capital has three types. They are authorized capital, issued capital, and paid-up capital. ${ }^{4}$ Authorized capital (statutair capital, nominal) is the entire nominal value of its shares stated in the Articles of Association..$^{5}$ The company's authorized capital is the total number of shares that the company can issue. ${ }^{6}$ The Articles of Association determine how many shares are used as authorized capital. The amount specified in the Articles of Association is a so-called pure nominal value. ${ }^{7}$ Authorized capital is the maximum capital issued by a limited liability company, entirely divided into shares. In other words, the limited liability company's authorized capital consists of the entire nominal value of the shares issued by the limited company concerned. The shares referred to both registered shares and appointed shares. The shares on behalf of are shares containing the holder or owner's name, while shares upon appointment are shares that do not include the holder or owner's name. ${ }^{8}$

Issued capital (subscribed capital) is capital committed by the founders or shareholders to be paid or deposited into the treasury of the Persero. ${ }^{9}$ Issued capital is several shares taken by the company founders or shareholders. Some of the shares taken have been paid for, and some have not been paid to the capital that the company founder or shareholders are willing to pay. The shares have been handed over to him to be owned. ${ }^{10}$ Paid-up capital (gestort kapitaal) is the company's capital in cash or other forms handed over to the founder to the company's treasury when the

4 Explanation of Article 41(1) of the Limited Liability Company Law No. 40 of 2007.

5 Rudhi Prasetya, Kedudukan Mandiri Perseroan Terbatas (Bandung: Citra Aditya Bakti, 1996) at 185.

6 Law No. 40 of 2007 on Limited Liability Companies, Article 31(1).

7 Yahya Harahap, Hukum Perseroan Terbatas (Jakarta: Sinar Grafika, 2019) at 233.

8 Rachmadi Usman, Dimensi Hukum Perusabaan Perseroan Terbatas (Bandung: Alumni, 2004) at 82.

9 Agus Sardjono, et al., Pengantar Hukum Dagang (Jakarta: Raja Grafindo Persada, 2014) at 83.

${ }^{10}$ Faisal Santiago, Pengantar Hukum Bisnis (Jakarta: Mitra Wacana Media, 2012) at 37. 
company was founded. ${ }^{11}$ It is the proportion of the nominal share paid by the shareholder. ${ }^{12}$

Issued and paid-up capital are outlined in Article 33 of the Limited Liability Company Law. This Article states (a) at least 25\% of the authorized capital must be issued and fully paid up; (b) the subscribed and fully paid-up a valid proof of deposit shall prove capital; and (c) any further issuance of shares to increase the issued capital must be fully paid up. ${ }^{13}$ In other words, at least $25 \%$ of the authorized capital has been placed and fully paid at the time of the company's establishment. Article 32(1) of the Limited Liability Company Law provides the company's authorized capital is the minimum of IDR 50,000,000.00 (USD 3,555). ${ }^{14}$ Then, Article 32(2) stipulates certain business activities that can determine a minimum amount of company capital more significant than authorized capital provision. ${ }^{15}$ Certain business activities referred to herein include banking, insurance, or freight forwarding (foreign investment companies). ${ }^{16}$ This article also states that a Government Regulation shall stipulate changes in the amount of authorized capital. ${ }^{17}$ The minimum limit of authorized capital as regulated in the most recent Limited Liability Company Law is increased from the minimum authorized capital in Article 25(1) of the 1995 Limited Liability Companies Law with a minimum of IDR 20,000,000.00 (USD 1,421). ${ }^{18}$

There was no provision regarding the minimum amount of authorized capital of a limited liability company in the Commercial Code. As a result, many fake limited liability companies were established under the Limited

\footnotetext{
11 Ridwan Khairandy, Pokok-Pokok Hukum Dagang Indonesia (Yogyakarta: FH UII Press, 2014) at 81-82.

12 Ibid at 75.

13 Law No. 40 of 2007, Article 33.

14 With an estimated currency of 1 USD equals IDR 14,000.

15 Ibid, Article 32.

16 Jamin Ginting, Hukum Perseroan Terbatas (UU No. 40 Tahun 2007) (Bandung: Citra Aditya Bakti, 2007) at 55.

17 Law No. 40 of 2007, Article 32(3).

18 Article 25(1) of Law No. 1 of 1995 on Limited Liability Companies.
} 
Liability Company Law 1995, and this attitude harmed the community. ${ }^{19}$ To anticipate this situation, the government determined the minimum amount of authorized capital for a limited liability company with USD 1,421. This mandatory minimum capital was added in Limited Liability Companies Law No. 40 of 2007. Legislators argued it was made to consider the precautionary principle. ${ }^{20}$ The subsequent justification that supports the minimum capital requirement was on the establishment of the company. It required the company to already has capital, which is the amount of paid-up capital. It also guaranteed third parties' claims against limited liability companies to guarantee third parties' guaranteed protection. $^{21}$ However, the provision on the minimum amount of authorized capital later was deviated through the issuance of Government Regulation No. 29 of 2016 that changes in the authorized capital of limited liability companies. Article 1(3) stipulates that the amount of authorized capital of a limited liability company is determined based on the agreement of the founders of the limited liability company, ${ }^{22}$ except for limited liability companies carrying out certain business activities, including banking and insurance. It was clarified in the general explanation of that government regulation as follows:

The provisions on the ease of doing business are in the form of changes to the Limited Liability Company's authorized capital, which was initially determined to be a minimum of IDR 50,000,000.00 to be fully submitted to the limited liability company's agreement founders. ${ }^{23}$

This general explanation confirms that this government regulation was formed to deviate Article 32(1) of the Limited Liability Company Law. It determined the minimum of authorized capital (from USD 3,555) that becomes fully submitted to the limited liability company's agreement founders. Some considered this deviation inappropriate to do in the form

19 Indonesian Ministry of Law and Human Rights, Laporan Akbir Kelompok Kerja Analisis dan Evaluasi Hukum terkait Badan Usaha, Laporan Evaluasi Hukum (Jakarta: Kementerian Hukum dan HAM, 2018) at 53.

20 Ibid.

${ }^{21}$ Handri Raharjo, Hukum Perusahaan Step by Step Prosedur Pendirian Perusabaan (Jakarta: Pustaka Yustisia, 2013) at 83.

22 Article 1(3) of Government Regulation No. 29 of 2016.

23 Ibid. 
of lower regulations than law (undang-undang) (in the hierarchy of Indonesian laws and regulations). The rules regarding the minimum limit of authorized capital are regulated in the law. Then, it was significantly amended after the government enacted the Job Creation Law. Article 109 that amended Article 32(1) and (2) of the Limited Liability Company Law states that a company must have its authorized capital. The amount of authorized capital company is determined based on the company's founding decision. ${ }^{24}$ Thus, the Job Creation Law clarifies and supports eliminating the minimum authorized capital limits.

There are several reasons to abolish the minimum limit of authorized capital. First, in the context of providing convenience in doing business and at the same time ensuring order in the business world about investment. Under the general explanation of Government Regulation No. 29 of 2016, it provides legal certainty for new entrepreneurs about national economic development, especially in starting a business. ${ }^{25}$ Second, on efforts to respect the principle of freedom of contract by giving the community the broadest possible freedom to enter into an agreement to establish a limited liability company based on civil law provisions. ${ }^{26}$ This provision is expected to encourage micro, small, and medium enterprises (MSMEs). ${ }^{27}$

On the other hand, the company's authorized capital should be a minimum of USD 3,555. It must be placed and fully paid up at least $25 \%$ or IDR $12,500,000.00$ (USD 711) in the Limited Liability Company Law. Some perceived it arduous, particularly for MSME entrepreneurs. ${ }^{28}$ In the academic paper on the Job Creation Law, the primary reason or initial

24 Article 109 of Law No. 11 of 2020 on Job Creation.

25 Eka Purnamasari, "Alasan Pembatasan dan Perubahan Ketentuan Terkait Modal Dalam Perseroan Terbatas” (2018) 5:1 Jurnal Magister Kenotariatan Fakultas Hukum UNISSULA 208 at 208.

26 Explanation of Article 1(3) of Government Regulation No. 29 of 2016.

27 Nanda Narendra Putra, "PP 29/2016 'Simpangi' Besaran Modal Dasar Pendirian Perseroan Terbatas" Hukumonline (2016) online: <https://www. hukumonline.com/berita/baca/1t57a205bfb73c9/pp-29-2016-simpangi-besaranmodal-dasar-pendirian-perseroan-terbatas $>$.

28 Indonesian Ministry of Law and Human Rights, Naskab Akademik Rancangan Undang-Undang Perseroan Terbatas (Jakarta: Kementerian Hukum dan HAM, 2016) at 42 . 
motivation for eliminating the minimum limit is to improve ease of doing business (EODB). It concludes by looking at the regulations regarding the requirements for establishing universities in various countries that no longer regulate and require minimum authorized capital again, like in Malaysia, referring to the Companies Act 2016 (Act 777) Article 9(b). The minimum authorized capital is also considered an obstacle to starting a business as one of the EODB assessment components. ${ }^{29}$

\section{PROS AND CONS OF MINIMUM CAPITAL REQUIREMENTS}

The debate of whether a minimum capital requirement for limited liability should be deregulated has been a topic for years in many countries. The minimum capital requirement requires incorporators to add to their company assets of the minimum value defined before their registration is permitted. ${ }^{30}$ This part provides theoretical and practical arguments of both advantages and disadvantages of removing the minimum capital requirement of limited liability and comparing it with other countries. It accounts for Doing Business in 2014; out of 189 countries, 99 countries did not have minimum requirements for companies. ${ }^{31}$ Some countries have never had these regulations, while 39 countries abolished them in 2014. ${ }^{32}$

Nevertheless, the primary and first motives are also the reasons behind the Job Creation Act, which encourages enterprise and entrepreneurship culture, especially for micro and small business. To encourage their expansion, micro and small businesses are seen as an engine of the economy. Thus, they should have the privilege to access limited responsibility in the form of a private limited liability company. Also,

29 Indonesian Ministry of Law and Human Rights, Naskah Akademik Rancangan Undang-Undang Cipta Kerja (2020) at 1301.

30 Gordon Y M Chan, "Why Does China Not Abolish the Minimum Capital Requirement for Limited Liability Companies?" (2009) Social Science Research Network at 4.

31 Doing Business, "Why are minimum capital requirements a concern for entrepreneurs?" Doing Business (2014) online: <https://www.doingbusiness.org/content/ dam/doingBusiness/media/Annual-Reports/English/DB14-Chapters/DB14-Whyare-minimum-capital-requirements.pdf >.

32 Ibid. 
public limited liability companies are generally more suitable for large companies. Minimum capital requirements (if not overly high) do not usually place major obstacles on them. ${ }^{33}$ Most public companies often have a much higher equity capital amount than mandatorily imposed by law. ${ }^{34}$ On the other hand, private companies are typically used by MSMEs, and many of them may struggle with their financing. ${ }^{35}$ With regard to economic results, the paper indicates that small and medium-sized businesses have less access to bank funding in economies with high minimum capital requirements. ${ }^{36}$ The minimum capital requirement may create barriers to MSMEs entering the market.

It has also proven useful in practice. Saudi Arabia is an example of a country that links entrepreneurship and the elimination of minimum capital requirements. The NCC observed in June 2006 that entrepreneurial activity in Saudi Arabia was low. ${ }^{37}$ It was influenced by starting a business, which took more than five weeks despite its expensive cost. In addition, it was one of the highest minimum capital requirements in the world, with the amount of USD 125,000. ${ }^{38}$ Under such old regulations, there were only 12,194 limited liability companies versus 646,900 sole proprietorships in Saudi Arabia. With the minimum capital requirement of USD 125,000, starting a limited liability company was too costly. Then, under Saudi Arabia Ministerial Decision No. 221/2007 that amended the previous capital requirements, the minimum capital requirements were removed. As a result, in one year, the country's rank in the ease of starting a business soared from 159 to 36 in Doing Business 2008, and new business

33 Fransisco Soares Machado, "Effective Creditor Protection in Private Companies: Mandatory Minimum Capital Rules or Ex Post Mechanisms?" (London: London School of Economics and Political Science, 2009) at 683-684.

34 Ibid at 684.

35 Ibid.

36 Doing Business, supra note 32.

37 Awwad Al-Awwad, "Eliminating Minimum Capital Requirement and Facilitating Business Start-Up in Saudi Arabia" World Bank (2007) online: <https:// openknowledge.worldbank.org/bitstream/handle/10986/10642/456600BRI0Box31ia 1Starting1Business.pdf>.

38 Ibid. 
registrations jumped 81 percent. ${ }^{39}$ Then, Saudi Arabia has successfully implemented this policy, although MSMEs did not contribute significantly to Saudi Arabia's gross domestic product (GDP). ${ }^{40}$ The Saudi Arabian petroleum industry contributed half of GDP but did not contribute much, i.e., 2 percent to employment. ${ }^{41}$ Thus, the reason for eliminating the minimum capital requirement in Saudi Arabia was entirely motivated to create job opportunities.

In 2019, Finland eliminated the minimum capital requirement, which was previously EUR 2,500 (USD 3,030) for a private limited liability company. The Ministry of Justice facilitated the profession's pursuit and other micro and small business activities without personal responsibility. ${ }^{42}$ The amendment is predicted to have an impact on the formation of 85 percent of limited liability companies. ${ }^{43}$ Besides, experts supporting the theory of eliminating minimum capital requirement also refuted the claim that the minimum capital requirement is necessary, namely for creditors' security. Hence, creditors' protection with minimum capital requirements is considered ineffective.

Economies that did not have or set deficient minimum capital requirements tended to help safeguard investors by encouraging corporate transactions transparency. They offered easy access to corporate information and ensured tighter directors' liability standards. ${ }^{44}$ Then, requirements did not play a crucial role in protecting creditors against company bankruptcies. It may because creditors are not protected primarily due to a misconception that creditors' security is primarily based on capital rather than assets. ${ }^{45}$ The meaning of capital here is the amount stated in the articles of association. Simultaneously, assets are the sum of all

39 Saudi Arabia also removed the procedural requirement from 13 to 7. Ibid.

40 Ibid.

${ }^{41}$ Ibid.

42 The Nomad Today, "Minimum Capital Requirement for Limited Liability Companies Will be Abolished" The Nomad Today (2019) online: <https://www. thenomadtoday.com/articulo/business-finland/the-minimum-capital-requirementfor-private-limited-companies-will-be-abolished/201902081337 00001287.html>.

43 Ibid.

44 Doing Business, supra note 32.

45 Chan, supra note 30. 
resources, such as cash, equipment, appurtenance, land, and accounts receivable. It is also found in practice, especially in countries where law enforcement is not very strict. There are legal infringements in the form of document fraud or secret capital withdrawal after company registration. ${ }^{46}$

The following graph shows the higher minimum capital requirements associated with the weaker creditor protection:

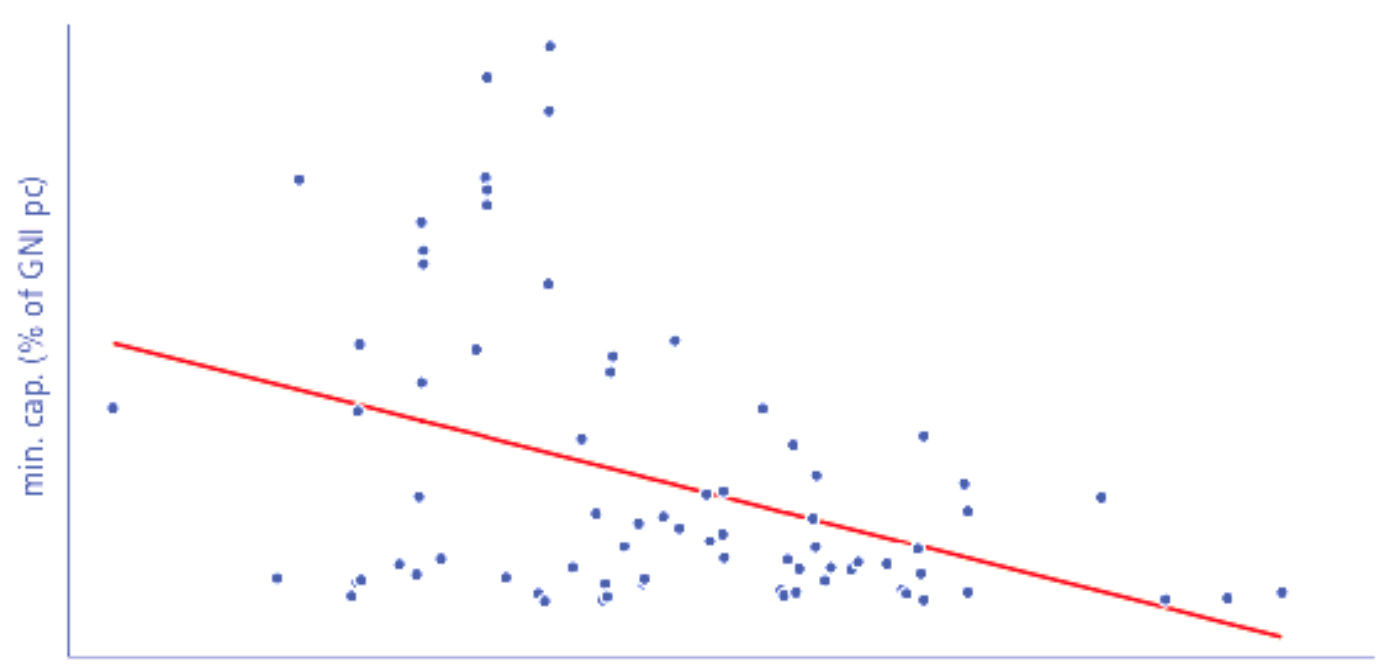

Strength of investor protection index

Figure 1. Capital requirements associated with the weaker creditor protection. ${ }^{47}$

In European jurisdictions, the proposed minimum capital requirement is regulated not less than EUR 25,000 (USD 30,300) at the time of first registration. ${ }^{48}$ The policy on minimum capital requirements was heavily criticized, and many countries in Europe dismantled it. ${ }^{49}$ This proposal was updated with a minimum of EUR 1 (USD 1.2). ${ }^{50}$ Based on the explanatory memorandum, creditors prefer to investigate aspects other than capital,

\footnotetext{
46 Ibid at 8 .
}

47 Ibid.

48 McCahery J A, Raaijmakers T \& Vermeleun E PM, The Governance of Close Corporations and Partnerships (Oxford: Oxford University Press, 2004) at 384.

49 Barnevald J, "Legal Capital and Creditor Protection: Some Comparative Remarks" in The European Private Company (SPE): A Critical Analysis of the EU Draft Statute" (2009) at 85 .

50 Ibid. 
such as cash flow, that are more relevant to solvency. ${ }^{51}$ Another argument is that creditors could protect themselves through a contract. ${ }^{52}$ Another objection is that unlimited liability businesses may reduce their liability by ensuring the business owner not to hold family assets. ${ }^{53}$ Likewise, unincorporated enterprises themselves may be undercapitalized. On this argument, it is illogical to require only a minimum capital under a limited liability scheme: a similar requirement should be imposed on all undertakings. ${ }^{54}$ There are two answers to this argument. First, in practice, owners of businesses without limited liability generally consider their assets to be at risk and proceed appropriately. ${ }^{55}$ Second, if the minimum capital requirement's objective is to signal the suitability of incorporation as a limited liability company, the argument does not apply. ${ }^{56}$

There are doubts as to the nominal value of the minimum capital requirements. There is a danger that, if the minimum value is very high, it could prevent an entity from entering the market and creating a monopoly. ${ }^{57}$ On the other hand, there is doubt that to protect creditors. The minimum value must be very high to achieve this objective. ${ }^{58}$ Given the growing variety of industries, it is difficult to apply a single standard to all industry types. Even though, as in Indonesia, some sectors have their minimum capital standards, such as banking and insurance. However, there are still many sectors that are equalized.

Historically, before the 19th century, establishing a company was solely within the competence of a State granted a privilege or authorization for that purpose. ${ }^{59}$ The liability limitation was an exception, as the member states treated large enterprises with suspicion. Consequently, a state would only allow legal entities to be formed if they had the financial means to

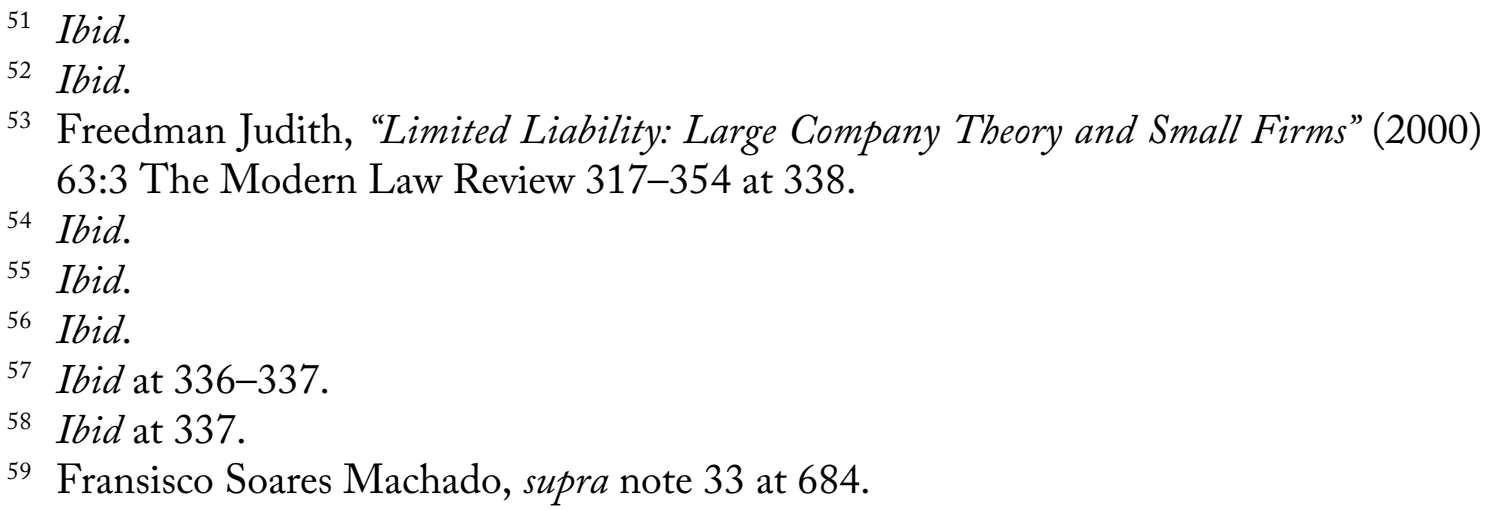


become successful firms.$^{60}$ It is accomplished to protect the country in the absence of potentially unsuccessful companies. However, when the corporate form was liberalized, the minimum capital rules were said to no longer serve the States' interests.

In the first place, the minimum capital requirements are considered to protect shareholders. If there were a minimum amount of funds that the company could use, entrepreneurs would be covered and discouraged from entering a hazardous investment. ${ }^{61}$ Then, transaction costs can be minimized by the minimum capital requirements. If the minimum capital requirements are entirely repealed, they would likely be replaced by contracts. ${ }^{62}$ These creditors will ask more of the company as companies negotiate with creditors and even seek the owners' guarantees. ${ }^{63}$ It takes more time for individual contracts and needs more analysis and materials, the costs are higher than for a generalized contract.

The main reason for the regulation of minimum capital requirements is to protect creditors from the misuse of limited liability benefits. Creditors, in principle, have a higher chance of not being paid. Therefore, there is a need for risk reallocation. ${ }^{64}$ It presumably will have lowered the risk of the company defaulting on its debts with a minimum capital requirement. ${ }^{65}$ The higher the minimum capital requirement, the stronger the protection for creditors. Besides, critics of the absence of a minimum capital requirement in the United Kingdom also stated that although creditors can protect themselves with contracts, there are also involuntary debtors (such as tort victims) who cannot protect themselves. ${ }^{66}$ Moreover, the minimum capital requirement's nominal value has a role in protecting minority

60 Ibid.

${ }^{61}$ Ibid at 685.

${ }^{62}$ Madelene Nelson, "The Share Capital Requirement: A Comparative Study of its Functions, Problems, and Future" (2013) Lund University.

63 Ibid.

64 Frank H Easterbrook \& Daniel R Fischel, The Economic Structure of Corporate Law (Cambridge: Harvard University Press, 1996) at 49-50.

65 Chan, supra note 30.

66 Barnevald J, supra note 49 at 87. 
investors by becoming collateral, which is at least equal to the minimum authorized capital fixed by the government. ${ }^{67}$

Minimum capital requirements also select the seriousness of the business to become a limited liability company. To become a limited liability company, there is a price to pay. Even if not high, it would thus amount to a symbolic price to pay for liability limitation. ${ }^{68}$ The following is a compilation of countries, from those that regulate minimum capital requirements and their nominal values and those that do not require a minimum capital, as follows:

\begin{tabular}{|c|c|c|c|}
\hline No. & Country & $\begin{array}{l}\text { Minimum } \\
\text { Capital } \\
\text { Requirement for } \\
\text { (Private) LLC }\end{array}$ & Nominal Values \\
\hline 1 & Argentina & No & \\
\hline 2 & Australia & No & \\
\hline 3 & Austria & Yes & $\begin{array}{l}\text { a. EUR 35,000 (USD 42,400) minimum share } \\
\text { capital, with at least EUR 17,500 (USD 21,200) } \\
\text { paid up in cash. } \\
\text { b. A GmbH privileged at foundation may be } \\
\text { established: the minimum share capital is EUR } \\
\text { 10,000 (USD 12,119), with a minimum of } \\
\text { EUR 5,000 (USD 6,060) paid up in cash. The } \\
\text { status as a GmbH privileged at foundation ends } \\
\text { after } 10 \text { years after registration at the latest. } \\
\text { c. Formation by contribution in kind is possible. }\end{array}$ \\
\hline 4 & Bahrain & No & \\
\hline 5 & Belgium & No & \\
\hline 6 & Brazil & $\begin{array}{l}\text { In principle, there } \\
\text { is no minimum } \\
\text { capital } \\
\text { requirement. }\end{array}$ & \\
\hline 7 & Canada & No & \\
\hline 8 & Chile & No & \\
\hline 9 & China & No & \\
\hline
\end{tabular}

${ }^{67}$ Xavier Nugraha, Krisna Murti \& Saraswati Putri, 'Third Parties' Legal Protection Over Agreed Authorized Capital Amount by Founders in Limited Liability Companies" (2019) 6:2 Lentera Hukum at 186.

${ }^{68}$ Fransisco Soares Machado, supra note 33 at 685. 


$\begin{array}{lll}10 & \text { Colombia } & \text { No } \\ 11 & \text { Czech } & \text { Yes } \\ & \text { Republic } & \\ 12 & \text { Denmark } & \text { Yes }\end{array}$

$\begin{array}{lll}13 & \text { Egypt } & \text { No } \\ 14 & \text { Finland } & \text { No } \\ 15 & \text { France } & \text { Yes } \\ 16 & \text { Germany } & \text { Yes } \\ 17 & \text { Greece } & \text { No } \\ 18 & \text { Hong Kong } & \text { No } \\ 19 & \text { Hungary } & \text { Yes } \\ 20 & \text { India } & \text { No } \\ 21 & \text { Ireland } & \text { No } \\ 22 & \text { Israel } & \text { No } \\ 23 & \text { Italy } & \text { Yes }\end{array}$

$\begin{array}{lll}24 & \text { Japan } & \text { Yes } \\ 25 & \text { Luxembourg } & \text { Yes } \\ 26 & \text { Malaysia } & \text { No } \\ 27 & \text { Mauritius } & \text { No } \\ 28 & \text { Mexico } & \text { No } \\ 29 & \text { Netherland } & \text { No } \\ 30 & \text { New Zealand } & \text { No } \\ 31 & \text { Nigeria } & \text { Yes } \\ 32 & \text { Norway } & \text { Yes } \\ 33 & \text { Philippines } & \text { Yes } \\ 34 & \text { Poland } & \text { Yes } \\ 35 & \text { Portugal } & \text { Yes } \\ 36 & \text { Puerto Rico } & \text { No } \\ 37 & \text { Romania } & \text { Yes } \\ 38 & \text { Russia } & \text { Yes }\end{array}$

CZK 1 (USD 0.05)

a. Entrepreneur company (ivarksatterselskab): DKK 1 (USD 0.16)

b. Private limited company (anpartsselskab): DKK 40,000 (USD 6,518)

c. Limited partnership company (partnerselskab): DKK 400,000 (USD 65,180)

USD 1.2

EUR 25,000 (USD 30,300)

HUF 3,000,000 (USD 10,100)

Minimum capital requirement of EUR 10,000 (USD 12,118). Law revisions introduced the possibility to incorporate a S.r.l. with a corporate capital of fewer than USD 12,118 provided that:

a. the corporate capital is minimum equal to USD 1.2

b. the entire amount must be paid in cash by the directors of the company and

c. a special reserve is formed to fill the gap in the capital with the future profits of the company

JPY 1 (USD 0.0095)

EUR 12,000 (USD 14,540)

NGN 10,000 (USD 24)

NOK 30,000 (USD 3,540)

PHP 5,000 (USD 103)

PLN 5,000 (USD 1,350)

EUR 2 (USD 2,42)

RON 200 (USD 50)

Russian Rubles 10,000 (USD 135) 


$\begin{array}{llll}39 & \text { Saudi Arabia } & \text { No } & \\ 40 & \text { Singapore } & \text { Yes } & \text { SGD 1 (USD 0.75) } \\ 41 & \text { South Africa } & \text { No } & \\ 42 & \text { South Korea } & \text { No } & \text { EUR 3,000 (USD 3,635) } \\ 43 & \text { Spain } & \text { Yes } & \\ 44 & \text { Sweden } & \text { No } & \text { CHF 20,000 (USD 22,300) } \\ 45 & \text { Switzerland } & \text { Yes } & \\ 46 & \text { Taiwan } & \text { No } & \text { THB 5 (USD 0,18) } \\ 47 & \text { Thailand } & \text { Yes } & \text { TLC 10,000 (USD 1,436) } \\ 48 & \text { Turkey } & \text { Yes } & \\ 49 & \text { Ukraine } & \text { No } & \\ 50 & \text { UAE } & \text { No } & \text { Any value above zero } \\ 51 & \text { United } & \text { No } & \\ & \text { Kingdom } & & \\ 52 & \text { United States } & \text { No } & \\ 53 & \text { Vietnam } & \text { No } & \end{array}$

Table 1. Countries that regulates and do not require minimum capital requirements ${ }^{69}$

Out of the 53 countries above, most countries do not have a minimum capital requirement. Some countries determining a minimum capital requirement do not reach each of their currencies' value to be considered non-existent. However, certain strict regulated sectors such as banking and insurance have their minimum capital requirements. For example, Vietnam applies minimum capital for the banking and non-banking sectors, such as financial companies, real estate, debt collection, security, film, auditing, telecommunications, mobile telecommunications, and transports, including air transportation.

\section{MINIMUM AUTHORIZED REQUIREMENTS RELEVANT TO INDONESIA'S BUSINESS}

Through the Job Creation Law, Indonesia emphasizes that the minimum authorized capital requirement no longer exists. ${ }^{70}$ It is arguably the right

69 The sorted data in this table are the general minimum capital requirements. Each country has its own rules for strictly regulated sectors and foreign companies. DLA Piper, "Guide to Going Global Corporate: Full Handbook" DLA Piper (2019) online: $<$ https://www.dlapiperintelligence.com/goingglobal/>. 
decision, by considering the comparisons made in the previous section between the advantages and disadvantages of the presence or absence of minimum capital requirements that overwhelmingly dominate the reasons for eliminating the minimum authorized capital.

There are several reasons for eliminating the minimum authorized capital in Indonesia. First, the opinion on the minimum authorized capital is intended to protect third parties is wrong; countries do not have minimum capital requirements or set them very low tend to protect investors better. Instead, it can be made by promoting transparency in corporate transactions, providing easy access to corporate information, and having stricter director liability standards. ${ }^{71}$ The existing rules regulate transparency in corporate transactions by providing easy access to corporate information. In Indonesia, that kind of regulation has been enacted by enacting Limited Liability Company Law in company data. ${ }^{72}$ Second, it is an effort to respect the principle of freedom of contract by giving the community the broadest possible freedom to enter into an agreement to establish a limited liability company based on civil law provisions. Third, it helps to improve the ease of doing business (EODB). Fourth, it encourages a culture of enterprise and entrepreneurship. Small firms are seen as an engine of the economy, which should have limited liability to grow. MSMEs usually use private companies, and many of them may struggle with their financing. Finally, given Indonesia's conditions, the number of micro-businesses dominates the Indonesian business units, 98.7\%, followed by small businesses, $1.2 \%{ }^{73}$ In other words, $99 \%$ of business units in Indonesia are MSMEs. Along with such conditions, these recent provisions set in the Job Creation Law eases to start a business by establishing a limited liability company by eliminating authorized capital that MSMEs need.

\footnotetext{
Article 109 of Law No. 11 of 2020.

Doing Business, supra note 31.

Article 29 (2) of Law No. 40 of 2007.

Dewi Meisari Haryanti \& Isniati Hidayah, "Potret UMKM Indonesia: Si Kecil yang Berperan Besar" UKM Indonesia (2018) online: <https://www.ukmindonesia.id/ baca-artikel/62>.
} 


\section{CONCLUSION}

The Job Creation Law has ended the regulatory debate regarding the minimum authorized capital requirements for Indonesia's limited liability companies. As a result, establishing a limited liability company does not require minimum capital. It is different from the previous rules, which required an amount of capital. The debates related to minimum capital requirements continue in various countries. On the one hand, the minimum capital requirement protects creditors from insolvent debtors; creditors have a higher chance of not being paid. Thus, it needs risk reallocation. On the other hand, several experts stated that the minimum capital requirement regulation was not effective in protecting creditors. It is ineffective because countries that do not have or set deficient minimum capital requirements tend to protect investors by encouraging transparency in corporate transactions, offering easy access to corporate information, and ensuring tighter directors' liability standards.

\section{ACKNOWLEDGMENTS}

None.

\section{COMPETING INTERESTS}

The authors declared that they have no competing interests.

\section{REFERENCES}

Al-Awwad, Awwad, "Eliminating Minimum Capital Requirement and Facilitating Business Start-Up in Saudi Arabia” World Bank (2007).

Anggono, Bayu Dwi \& Fahmi Ramadhan Firdaus, "Omnibus Law in Indonesia: A Comparison to the United States and Ireland" (2020) 7:3 Lentera Hukum.

Aziz, Muhammad Faiz \& Nunuk Febriananingsih, "Mewujudkan Perseroan Terbatas (PT) Perseorangan Bagi Usaha Mikro Kecil (UMK) Melalui 
Rancangan Undang-Undang Tentang Cipta Kerja" (2020) 9:1 Rechstvinding.

Chan, Gordon Y M, "Why Does China Not Abolish the Minimum Capital Requirement for Limited Liability Companies?" (2009) Social Science Research Network.

DLA Piper, “Guide to Going Global Corporate: Full Handbook” DLA Piper (2019) online: <https://www.dlapiperintelligence.com/goingglobal/>.

Doing Business, "Ease of Doing Business Rankings" Doing Business (2019) online:<https://www.doingbusiness.org/en/rankings>.

Doing Business, "Why are minimum capital requirements a concern for entrepreneurs?" Doing Business (2014) online: <https://www. doingbusiness.org/content/dam/doingBusiness/media/AnnualReports/English/DB14-Chapters/DB14-Why-are-minimumcapital-requirements.pdf>.

Easterbrook, Frank H \& Daniel R Fischel, The Economic Structure of Corporate Law (Cambridge: Harvard University Press, 1996).

Ginting, Jamin, Hukum Perseroan Terbatas: (UU No. 40 Tahun 2007) (Bandung: Citra Aditya Bakti, 2007).

Harahap, Yahya, Hukum Perseroan Terbatas (Jakarta: Sinar Grafika, 2019).

Haryanti, Dewi Meisari \& Isniati Hidayah, "Potret UMKM Indonesia: Si Kecil yang Berperan Besar" UKM Indonesia (2018) online: <https://www.ukmindonesia.id/baca-artikel/62>.

Indonesian Ministry of Law and Human Rights, Naskah Akademik Rancangan Undang-Undang Cipta Kerja (2020).

Indonesian Ministry of Law and Human Rights, Naskah Akademik Rancangan Undang-Undang Perseroan Terbatas (Kementerian Hukum dan HAM, 2016).

Indonesian Ministry of Law and Human Rights, Laporan Akbir Kelompok Kerja Analisis dan Evaluasi Hukum terkait Badan Usaha (Jakarta: Kementerian Hukum dan HAM, 2018). 
J A, McCahery, Raaijmakers T \& Vermeleun E PM, The Governance of Close Corporations and Partnerships (Oxford: Oxford University Press, 2004).

J, Barnevald, "Legal Capital and Creditor Protection: Some Comparative Remarks" in The European Private Company (SPE): a Critical Analysis of the EU Draft Statute (2009) 81.

Judith, Freedman, "Limited Liability: Large Company Theory and Small Firms" (2000) 63:3 The Modern Law Review 317-354.

Khairandy, Ridwan, Pokok-Pokok Hukum Dagang Indonesia (Yogyakarta: FH UII Press, 2014).

Machado, Fransisco Soares, Effective Creditor Protection in Private Companies: Mandatory Minimum Capital Rules or Ex Post Mechanisms? London School of Economics and Political Science, 2009.

Nelson, Madelene, "The Share Capital Requirement: A Comparative Study of its Functions, Problems, and Future" (2013) Lund University.

Nugraha, Xavier, Krisna Murti \& Saraswati Putri, 'Third Parties' Legal Protection Over Agreed Authorized Capital Amount by Founders in Limited Liability Companies" (2019) 6:2 Lentera Hukum.

Purnamasari, Eka, "Alasan Pembatasan dan Perubahan Ketentuan Terkait Modal Dalam Perseroan Terbatas" (2018) 5:1 Jurnal Magister Kenotariatan Fakultas Hukum UNISSULA 208.

Prasetya, Rudhi, Kedudukan Mandiri Perseroan Terbatas (Bandung: Citra Aditya Bakti, 1996).

Putra, Nanda Narendra, "PP 29/2016 'Simpangi' Besaran Modal Dasar Pendirian Perseroan Terbatas" Hukumonline (2016), online: <https:// www.hukumonline.com/berita/baca/lt57a205bfb73c9/pp-29-2016simpangi-besaran-modal-dasar-pendirian-perseroan-terbatas $>$.

Raharjo, Handri, Hukum Perusabaan Step by Step Prosedur Pendirian Perusahaan (Jakarta: Pustaka Yustisia, 2013). 
Santiago, Faisal, Pengantar Hukum Bisnis (Jakarta: Mitra Wacana Media, 2012).

Sardjono, Agus, et al., Pengantar Hukum Dagang (Jakarta: Raja Grafindo Persada, 2014).

The Nomad Today, "Minimum Capital Requirement for Limited Liability Companies Will be Abolished" The Nomad Today (2019) online: $<$ https://www.thenomadtoday.com/articulo/business-finland/theminimum-capital-requirement-for-private-limited-companies-willbe-abolished/2019020813370000128 7.html>.

Usman, Rachmadi, Dimensi Hukum Perusahaan Perseroan Terbatas (Bandung: Alumni, 2004). 
22 | Minimum Authorized Capital After the Enactment of Job Creation Law

This page intentionally left blank 